\title{
The United Nations, Conflict Management and Spheres of Interest
}

\author{
TERRY TERRIFF and JAMES F. KEELEY
}

The initial promise of the UN being able to manage conflicts with the ending of the
Cold War has faded. Historically, the ability of the UN to act has been strongly
influenced by the interests of its member states, especially the major powers, and a
number of factors, such as threat, type of response, limitations on UN action, and
degeneration of a situation, have affected the ability of the UN to respond and respond
successfully. These and other factors can be organized to define a 'window of
opportunity' for successful UN action. The 'window' concept suggests that in the
current era, where most conflicts have little impact on the wider international system,
the major powers are likely to be motivated only to manage those conflicts which
affect their interests. This will have significant implications for the UN as a conflict
manager.

\section{Introduction}

At the end of the Cold War it seemed possible that the United Nations could assume the leading role in managing conflict. After some initial success, especially with the closing of Cold War-related situations, the promise of the UN as a conflict manager has waned. While challenges are growing quickly, the UN has become overstretched. The UN increasingly has difficulty in defining a consensus for intervening militarily in disputes, developing agreement to provide mandates that link military operations closely to the satisfactory fulfilment of established goals, and finding the financial, material and manpower resources needed to mount appropriate military operations.

The central problem is that member states are increasingly reluctant to become engaged in, or to bear the cost of, UN military operations deployed to manage crises which they see as having little significance to their interests, though they may yet have the will to exert themselves where those interests are seen as affected. The dilemma this poses for the UN was captured by Secretary-General Boutros Boutros-Ghali in early March 1995 at a conference on peacekeeping in Vienna, when he suggested that the

Terry Terriff is Lecturer in the Department of Political Science and International Studies at the University of Birmingham, UK.

James Keeley is Associate Professor in the Department of Political Science at the University of Calgary, Canada.

International Peacekeeping, Vol.2, No.4, Winter 1995, pp.510-35

PUBLISHED BY FRANK CASS. LONDON 
organization might in future have to 'contract out' more conflict management operations to regional organizations or multinational forces led by major powers with special interests in the disputes.' Such a possibility concerns many analysts as it implies a return to an international order governed by spheres of influence or interest. ${ }^{2}$

The ability of the UN to respond to conflicts, its patterns of action, and its likelihood of acting successfully have historically been strongly influenced by and responsive to the interests of its member states, most particularly the major powers. ${ }^{4}$ As a consequence, the UN may be unwilling to do more than contain (if that) conflicts that do not affect the interests of the major powers. One implication of this conclusion is that the UN will only be able to act forcefully and successfully when its goals are quite modest or the major powers will it to do so. In the case of the latter, the circumstances which are most likely to engage or threaten their interests will reflect the politics of spheres of interest.'

The first part of this article will develop the connection between past patterns of UN involvement and success on the one hand and sphere of interest considerations on the other. This will be done through the statement of a 'window of opportunity' argument, which sets out some conditions in which the UN appears to have been particularly active and successful in dealing with conflict. This part concludes with an examination of how this window has been modified by a changing international environment and the willingness of major powers to move through it for sphere of interest considerations. The second part of this article examines three cases of big power action: the former Yugoslavia, Rwanda and Haiti. Implications of the argument are then noted in our conclusions.

\section{The Window of Opportunity and Spheres of Interest}

A number of at least semi-quantitative studies have examined patterns of conflict management by the UN, among other actors, searching for conditions which lead to involvement by such actors in these efforts and which might affect their success. Their various findings cannot be readily accumulated, since they involve different definitions, variables, sets of disputes, time periods, specific concerns, and so on. Nonetheless, we argue that there is some commonality in their results, an accretion pointing to some generalizable statements. We do not, therefore, claim to offer a new empirical analysis as such, but rather a broad concept which seems to have some utility in organizing existing findings and which has some possibility of policy or even theoretical relevance. This broad concept is the 'window of opportunity', which may facilitate the identification of factors influencing UN conflict resolution activities, possible remedies for limitations, and 
factors which may restrict such solutions. We also contend that this "window of opportunity' demonstrates significant sphere of interest effects.

The window concept organizes various considerations, such as success, response type, and possibilities of degeneration or escalation in a dispute, into a group which suggest both limits on, and possibilities for, UN (and other managers') action.' The window metaphor suggests both a lower threshold, below which serious or resource-significant actions will not be attempted, and other limits on involvement and effectiveness. Taken together, these could suggest curvilinear patterns of involvement and success. Dynamically, various considerations can be raised. Considerations of the path and the rate of movement of the dispute (especially its rate of degeneration or escalation) relative to the speed of response, and to the ability of the responding actor to 'steer' it (thus scale, objective and mandate of its action) may be phrased in these terms. In addition, the possibility that the window itself may change over time, opening up or restricting the scope for successful action, may also be addressed. We do not attempt to develop the full potential of the concept here, but rather simply try to sketch some initial suggestions.

A common observation in the studies examined is that more consequential or intense conflicts tend to result in UN engagement, more substantial engagement, and more successful engagement, than do less consequential or intense disputes. ${ }^{\text {II }}$ It was more probable that the UN would respond, and do so strongly and successfully, as the level of actual or possible violence increased." On the other hand, situations which were or were perceived to be less threatening did not lead to substantial cfforts, and these efforts were not as successful." The perceived gravity of a conflict, especially in terms of its impact beyond the state(s) involved, will thus affect whether the UN becomes active in an attempt to manage it, and the success of that effort. This group of findings suggests, first, a rough lower level or threshold of involvement, below which a dispute is unlikely to call for a significant control attempt (especially one requiring the use of major military resources), ${ }^{11}$ and second, the upward leg of our suggested curvilinear pattern of involvement and success. ${ }^{12}$ Beyond this, a further possibility may emerge; the scale and mandate of a $\mathrm{UN}$ involvement may also be a factor affecting success, combining with the attributes of the conflict situation in a dynamic way as the tendency of a given conflict to degenerate meets a UN response which may catch up with, check, reverse or fall behind this propensity. The first and last possibilities point to the troubling phenomena of 'mission creep' and 'mission lag'."

There also seems to be an upper limit on involvement and effectiveness; thus the relationship between involvement and success on the one hand and the degree and kind of threat on the other may be curvilinear rather than 
simply linear. While a lower threshold of threat must be surpassed before significant action is taken, it is also possible for a conflict to deteriorate beyond the control of the operation undertaken, or even never to fall into the window. For the first, there is some evidence to suggest that as the level of violence grew the organization's success might initially rise and then drop off as the dispute escalated from intense fighting for limited aims to intense fighting to destroy an enemy, or as a conflict widened from a bilateral one, to including bordering states, to drawing in significant third party involvement from elsewhere. ${ }^{.4}$ As the situation degenerates, the dangers of intervening and the effort needed to intervene successfully may increase rapidly. In particular, the willingness of the parties to a conflict to reduce the level of violence, much less stop fighting, may suffer. Traditionally, peacekeeping operations have depended on first stabilizing a ceasefire which the force could then maintain, not on moving into an ongoing combat situation. For the second, there are observations that the UN was less successful, and less likely to get involved, in managing intra-state conflicts (whether or not these were Cold War related) than de-colonization and other interstate (but not Cold War-related) conflicts. ${ }^{15}$ Threats of unwelcome spread or involvement may trigger management efforts, but once significant outside parties become seriously engaged on one side or another it may be very difficult to mount, much less succeed in, a management effor. Thus, the intensity and scale of conflict on the one hand, and the kinds of issues engaged by a dispute on the other, could help define the limits of involvement, an upper boundary to the window.

The studies examined further suggest that alignment, the degree of escalation, and the power of the disputants are also factors which affect UN conflict management operations. All of these could bear on sphere of interest considerations.

Alignments strongly affected UN involvement and success prior to the late 1980s. Major power support for, toleration of, or participation in a UN operation seem to be a necessary condition if the operation was to get underway or if it was to achieve significant success. ${ }^{16}$ However, while UN involvement is associated with major power involvement, the reverse is not necessarily the case. ${ }^{17}$ Peacekeeping was one means by which the two superpowers in particular could limit the possibility of being drawn directly into conflicts of secondary interest, but they would not permit significant independent involvement in situations of direct and crucial interest to them. ${ }^{1 x}$ A threat of undesired spread might lead them to turn to the UN as a distancing and controlling mechanism, but once strong and direct involvement had occurred UN intervention appeared to be much less welcome and much less likely to succeed. "Thus, the prospect of escalation could trigger UN action, while a lower risk of escalation might not, but only 
to the point where those with partisan sympathies who might have acted to control the situation had not yet been drawn in. ${ }^{20}$

Alignment also shows as a factor in other ways. First, direct disputes between blocs were relatively unamenable to UN action." Second, to a lesser degree, intra-bloc disputes were also relatively unamenable to UN action. ${ }^{22}$ A bloc leader would not want broader involvement in a bloc's internal troubles, as it would prefer to keep external actors out unless the possibilities for bloc self-management efforts seemed unlikely to work. ${ }^{23}$ Third, disputes among non-aligned states were relatively less amenable to UN action, suggesting that the non-aligned preferred to keep outsiders, particularly the superpowers, out. ${ }^{24}$ The possibility of UN intervention in situations where alignment was a significant factor was present only when one or both superpowers were concerned about escalation, desired to cut their losses, or could not think of any other means to keep the conflict from getting worse. ${ }^{2 s}$

A different pattern, however, is apparent when the disputes were between aligned and non-aligned states - especially when the former attacked the latter - for these were relatively more amenable to UN conflict management efforts. The suggested reason for this is that the aligned state's bloc would be interested in preventing the non-aligned victim from shifting to the opposing camp. ${ }^{25}$ Thus, alignment appears to have limited the ability of the UN to act, and to act successfully, when dealing with disputes within and between blocs, while there seems to have been greater opportunities for the UN to act in situations that could affect existing alignments or that could draw the superpowers into situations in which they had only limited interests. This suggests that the major powers will likely prefer to manage themselves those conflicts that occur within their spheres of influence, and, where possible, spheres of interest, rather than have outsiders involved; they will resort to the UN only when they are unable to manage the problem unilaterally, or if they wish to disengage or remain disengaged.

Escalation within an internal conflict (when it did not have implications for alignment), could also affect UN involvement and success. Internal wars which subsided quickly and remained within national boundaries were unlikely to generate much concern. Prolonged internal wars that threatened to spill over boundaries, however, were more likely to be of concern to regional interests. ${ }^{27}$ This suggests that the more localized the effect of a conflict, the less likely it would be to provoke UN management efforts and the more likely to lead to a response by a neighbouring, interested party or regional organization. ${ }^{2 *}$ As noted, the prospect of escalation could trigger UN involvement, but the actual spread of the conflict could then become an obstacle.

The power of the parties involved in a dispute is also connected to 
patterns of success and failure. Disputes involving one superpower or another large state with a weak state were not handled well, except where the stronger party wanted to withdraw from the situation. ${ }^{24}$ The limited opening for UN involvement in such asymmetric disputes stemmed from a lack of consensus among member states and from the unwillingness of the superpower or large power, such as the US, to relinquish its unhampered unilateral freedom' to act."

These broad, if complex, patterns suggest a number of implications for the changing conflict environment of the UN. A principal reason for UN involvement has been the fear that a conflict might connect to larger rivalries and escalate to draw in the superpowers; the UN could be used to check this tendency, if it was undesired. The ending of the Cold War means that local conflicts no longer link to the larger rivalries or interests. If such conflicts are peripheral to the issues and the interests which move major world issues, they will decline in salience. There then may be an associated decline in the willingness to devote major political, military, diplomatic or financial resources to handling them. As Ernst Haas notes, a marginalization of disputes may mean that member states are likely to tolerate conflict rather than to manage it'."

Other transformations in the post-Cold War world also point to a possible narrowing of the window of opportunity. Not only has the Cold War rivalry ended, but there also has been a decline in interstate war and an increase in civil wars. ${ }^{22}$ This shift has been reflected in the character of the UN's conflict management efforts. " Between 1988 and 1995 there were 21 new peacekeeping missions. Of these, only four were interstate, two of which were connected to internal disputes. ${ }^{34}$ The rest were internal, of which possibly six were Cold War related. ${ }^{\text {is }}$

The states involved in these conflicts have generally been of little global importance. " The interests which are affected by them are primarily local, through the threat of spillover, or are largely humanitarian. We would thus expect the willingness of the world to respond, especially major outside powers, to decline, and involvement to tend to be rather restricted. This could lead to a pattern of such interventions which do occur being relatively small, limited in mandate, and potentially inadequate in the face of a degenerating situation.

Yet internal disputes could be particularly prone to degeneration and thus require relatively large and rapid forces with more extensive mandates in order to be controlled. Internal conflicts are often based on deep, abiding and complex problems, characterized by multiple groups or subgroups whose overriding interest may be communal or ethnic survival, geographical intermixing of these competing groups or subgroups, guerrilla or other operations in which there is no obvious front line, the use of force against 
civilians, and a lack of discipline and centralized command and control." Most of these features depart substantially from the 'classic' interstate peacekeeping operations, which by contrast deal with relatively organized and disciplined forces, and relatively clear divisions. The particular features of internal conflicts make them especially prone to degeneration, and to require long-term efforts and large-scale resource commitments to control, even as they may discourage the commitment of such resources.

Thus the window of opportunity could be narrowing. The initial willingness of states to become involved could be declining; the lower threshold of the window moves up. Such operations as do occur may be slower, smaller than needed, and have an inadequate mandate. They thus may be unable to prevent degeneration - or even be too slow to prevent it and so the upper threshold (when the prospects of control become dim) may be approached quite rapidly. The very recognition of these dynamics may itself further discourage action, yielding a self-fulfilling prophecy of impotence and a self-reinforcing dynamic of failure.

This suggests a greater reluctance to support or engage substantially in efforts to manage local conflicts, also raising the initial threshold of involvement. States, especially major actors outside of the immediate area, may be unwilling to do more than the minimum necessary to prevent conflicts from impinging on their interests or assuage public demands for action. ${ }^{\text {Th }}$ Limited interest will likely only call forth limited, possibly largely symbolic rather than effective, responses. Major powers are more likely to be responsive to conflicts that occur within their spheres of influence or interest, as these are more likely to jeopardize their interests. Instead of NIMBY ('Not In My Back Yard'), their attitude may tend to be MIMBY ('Mainly In My Back Yard'). Where major powers in particular wish to intervene more vigorously, they may prefer to do so unilaterally or through a regional organization which they are better able to control. Should they seek to act through the UN, they may find other member states - responding to the same considerations - resisting the burden of action, at least to the point of being unwilling to participate, because their interests are not endangered.

To the extent that the UN is dependent on the active support (that is, contributions of forces, funding, logistics, or other material needs of UN operations) or passive support (that is, political backing) of the major powers, the propensity of major powers to act mostly only to protect or further their interests creates a number of problems for the organization. The UN increasingly may be unable to respond, or respond adequately, to disputes which do not significantly affect the interests of the major powers. Such an argument has a number of potential implications. First, many conflicts will be left to progress without outside responses other than 
diplomacy or containment. Second, the UN may be placed in the position of acting only when to do so protects or furthers major power interests, and/or providing international legitimacy to what are basically unilateral actions.

\section{The UN, Post-Cold War Conflicts and Spheres of Interest}

The narrowing of the window of opportunity in the post-Cold War period is highlighted in the cases of the former Yugoslavia, Haiti and Rwanda. ${ }^{34}$ Common to these cases has been a general reluctance to become involved, and when the UN did eventually engage it often did so in a limited manner or not until it was too late. In contrast to this, in each case a single state has acted on its own or at the head of a UN-mandated coalition to protect particular interests at stake in the dispute. The motivations for these states to become more actively and forcefully involved reflect sphere of interest considerations.

\section{The Former Yugoslavia}

The unwillingness of the major powers either to engage in the crisis in the former Yugoslavia or to commit the resources necessary to achieve satisfactory outcomes delineates a high initial threshold for UN success. The major powers were so determined to stay out of the Balkans conflict, to avoid stepping over the lower threshold of the window, that when they did engage they did so too late. The continued degeneration of the situation, coupled with the reluctance of the major powers to commit enough forces with an appropriate mandate, meant that the only satisfying outcomes were progressivcly beyond reach. The continuous degeneration of the conflict indicates a lowering upper boundary for successful UN activity.

The window of opportunity for successful action has been narrowest in the case of the United States, the big power most determined to avoid any direct military participation beyond providing the minimum necessary support for its diplomatic cfforts. This determination has stemmed from its perception that it has only limited interests involved and its concern that any direct engagement would result in it becoming embroiled in a military quagmire. In particular, the United States has been adamant about not permitting American military forces to become directly involved, or at least to stringently limit their involvement, in the conflict even as peacekeepers. ${ }^{40}$ The exception to this policy has been the strong American support for and participation in the UN monitoring force on the border between Macedonia and Kosovo (Serbia).

Yet the United States has been relatively active in responding to developments in the situation in the former Yugoslavia that endanger European stability and the American position in Western Europe. The 
spread of the war in the former Yugoslavia to Bosnia in the spring of 1992 convinced the United States that the conflict had no natural boundaries and that it might escalate into a wider Balkan war. Up until late May/early June 1992 the United States played only a passive role in the international effort to deal with the war in the former Yugoslavia, permitting the West Europeans to take the lead. Once it became clear that the war had spread to engulf Bosnia, however, the United States moved to become more directly engaged in and supportive of international efforts to deal with the Yugoslav crisis." The United States subsequently pushed for and participated in a number of UN-mandated initiatives, such as the naval embargo and airexclusion zone, which were designed to dampen any intensification of the war.

Fear that there might be a further widening of the war, however, stemmed most immediately from the prospect that the Serbian government might seek to drive ethnic Albanians out of the province of Kosovo. Any ethnic conflict in Kosovo in all likelihood would result in Macedonia being drawn in, with other states such as Albania, Greece, and Turkey subsequently also becoming involved. Such a wider Balkan war would pose a serious challenge to European stability, due either to pressures for other European states to become engaged or to the generation of massive refugee flows. Such a war would also see two NATO allies fighting on opposite sides, which could seriously, if not fatally, damage the alliance, through which the United States has long exercised its leadership position in Europe.

The spark that could lead to the 'nightmare scenario', as it came to be termed, was seen to be the development of open hostilities between the Serbian government and ethnic Albanian Muslims in Kosovo. The United States has sought to temper any inclinations that Serbia might have to use military force to assert its control in this province. In December 1992 the United States supported Security Council Resolution 795, which authorized the deployment of a UN force to monitor the border between Kosovo and Macedonia. Moreover, the United States was sufficiently concerned to undertake a number of unilateral steps. In late December 1992, President George Bush sent a letter to the Serbian leadership in which he warned that 'in the event of conflict in Kosovo caused by Serbian action, the United States will be prepared to employ military force against the Serbs in Kosovo and in Serbia proper'. ${ }^{42}$ In February 1993 the Clinton administration publicly reinforced the US warning to Serbia ${ }^{43}$ and subsequently volunteered to contribute some 300 American soldiers to the UN force deployed along the Macedonia-Serbian border. ${ }^{44}$ Secretary of State Warren Christopher characterized the purpose of the US decision as being 'to contain the conflict', "s with the US troops deployed to Macedonia being a 'deterrent force' that would have 'both symbolic and tangible value'. the 
US warning to Serbia and its willingness to provide an American presence in the UN peacekeeping force in Macedonia were concrete signals of its determination to safeguard the interests it perceived to be in jeopardy should the war intensify to engulf the larger Balkan region.

The US response to the explosive potential of the Macedonia/Kosovo situation, though the most exceptional American activity in the Yugoslav crisis, has not been the only instance in which the United States appeared to be motivated to become more engaged because of sphere of interest considerations. In early 1994, after a year of relative inactivity, the United States energetically pushed for the enforcement of an exclusion zone around Sarajevo and subsequently around other designated safe havens. President Bill Clinton, justifying the action, stated that 'we have an interest in showing that NATO...remains a credible force for peace in post-cold war Europe'. ${ }^{47}$ Clinton's public articulation of this reason is significant, for it was the only interest he discussed that Secretary of State Warren Christopher did not set forth a year earlier to explain the administration's carly Yugoslav policy. This strongly suggests that concern about the effectiveness of NATO as the primary defence institution in Western Europe was a key, if not the key reason, for the shift in US policy at this time. ${ }^{4 *}$

Just over a year later, in the late spring of 1995, the upsurge of fighting in Bosnia that was conducted in disregard of, and at times directed at, UN peacekeeping forces, raised growing concern that events were running out of control and, with the French threatening to pull out, that the UN operation was about to collapse. Secretary of State Warren Christopher made the American position clear, saying: "the option that is strongly preferred is that Unprofor [sic] should be strengthened, Unprofor should not be withdrawn'. The reason, as Secretary of Defense William Perry put it, was that 'the problems we are facing in Bosnia today, as bad as they are, could become much worse if the U.N. forces were withdrawn' ${ }^{\text {sh }}$ On the one hand, to end the UN operations would remove an important check on the possible escalation of the conflict, which the United States did not want to occur. and, on the other, it would force the United States to honour its earlier commitment to provide thousands of troops to assist in a UN withdrawal, which would compromise Washington's desire to avoid involving American troops on the ground in Bosnia. In an effort to forestall the withdrawal the Clinton administration stated that, if asked by the Europeans, the United States would be willing to provide American forces to assist in relocating UN forces, because it had to honour its commitment to its NATO allies. For the United States not to honour its commitments to its European allies, according to Robin Renwick, the British ambassador to Washington, 'would have tremendous consequences for the alliance'." A failure by the United States to help its allies would call into serious question its leadership in 
NATO and its position in Europe..$^{52}$ The Clinton administration recognized that if it was to avoid the policy dilemma posed by a UN withdrawal from Bosnia, it could no longer defer to the European lead; ${ }^{37}$ as a consequence, the United States in the summer of 1995 assumed a leadership role in the international efforts to stem the escalating fighting in Bosnia and move the conflict towards some sort of settlement. Whether the US decision to become more forcefully engaged in the conflict in Bosnia will result in some form of temporary or lasting peace as yet remains to be seen.

The United States for the most part has acted to secure its goals within the framework of the UN, while the exceptional unilateral warnings to Serbia generally support UN aims. Until the spring of 1995, the United States generally sought to avoid becoming directly engaged in the former Yugoslavia, with its most distinct efforts having been directed to protecting its interest in a stable Europe and a functional NATO rather than to compelling a cessation of fighting. The threat the Yugoslav conflict posed to American interests in Europe had been not been substantial, and the United States had been unwilling to do more than the minimum necessary to protect those interests. The deployment of a small, largely symbolic, contingent of American military personnel to Macedonia so far has been enough to define the limits of US toleration in that area of the region, while its willingness to push for and participate in air attacks has served to restore some credibility to NATO and the American leadership role in the alliance. In the spring and summer of 1995 , events in Bosnia forced the United States, if it was to secure its interests in the region while avoiding having to commit American ground forces, to become even more deeply engaged in finding a diplomatic solution.

Rwanda

In Rwanda, the primary concern of the major powers was to avoid at all costs becoming involved in the civil strife. This reflected a high threshold of involvement. The pace of events easily outran the limited efforts undertaken, indicating a rapid escalation towards the upper threshold. The one exception to the major powers' reluctance was the belated decision by France to intervene in the southern region of Rwanda.

France's intervention was clearly motivated by sphere of interest considerations. French Prime Minister Edouard Balladur was not shy in indicating that such considerations played a central role in that decision when other states were seeking to stay well clear of the carnage:

France sees itself as a world power. This is its ambition and its honour and I wish to preserve this ambition. And its main field of action is Africa, where it has an important role to play because of long-standing tradition - especially in French-speaking Africa. ${ }^{\text {s4 }}$ 
France has long sought to develop and maintain a special relationship not only with its former colonies but with other states in Africa to protect political, economic, and cultural interests on the continent. It has extended protection, defence and respect to the governments of African states which have been willing to open doors to French companies, supply campaign funds to French political parties, and provide political support for France in the UN and la francophonie. It maintains strong military ties with Africa. with more than 8,000 troops permanently stationed in seven African states ${ }^{55}$ and military agreements with 35 African countries, and has intervened militarily in nine French speaking countries over the past 32 years. ${ }^{86}$

In the case of Rwanda, since 1990 France had supported the Habyarimana government, dominated by French-speaking Hutus, in its war with the Rwandan Patriotic Front (RPF), with the deployment of a small garrison of French troops and the provision of military equipment. The credibility of France's support for African regimes could suffer if it failed to act at least to protect the Hutus from the RPF. The French intervention in Rwanda reminded other African states that France would be willing to use its military force to protect its friends and interests in the region. ${ }^{57}$ In addition, it was most unlikely that the Uganda-based and -supported RPF members would look favourably on the foreign power that had supported the Habyarimana government against them, raising the possibility that France may have hoped to be able to keep Rwanda within the francophone sphere of influence. ${ }^{5 *}$

The French intervention also served to demonstrate to other European states that France was a world power willing and able to lead and act decisively when others, especially the United States, were not. France may have been motivated in part by a desire to assert its influence in defence and security affairs in Europe at the expense of American influence on the continent. It attempted to pull together a coalition of Western European Union (WEU) members to intervene under the aegis of that organization. Success in this would have further promoted France's leadership role in Europe and forwarded its ambition to make the WEU the foremost organization responsible for West European security in place of NATO.

The French forces which entered into Rwanda had only a limited mandate, to establish a protection zone for a period of two months, effectively implementing the actions being pushed by the United States in the Security Council. France's sphere of interest objectives were limited and could be achieved with a small operation with limited objectives that did not run risks or incur costs that could outweigh any benefit obtained. The presence of the French forces stalled the advance of the RPF and served to protect Hutus within the zone from potential Tutsi reprisals until UN monitoring forces could move into the area. France's actions may have 
forestalled another round of horrible slaughter if the Tutsis were intent on taking revenge, but whether this would have occurred without the French presence is uncertain. For the most part, however, the limited mandate of the French forces meant that they withdrew after two months without having had any significant effect on the situation in Rwanda.

France had a number of incentives for obtaining a UN mandate for its intervention. First, a UN mandate would provide France with international support and legitimacy for its actions, even while these furthered French interests. Second, obtaining a UN mandate meant that France could claim that it was acting to advance the organization's humanitarian objectives in Rwanda until the UN peacekeeping force could be deployed. This limited France's responsibility, ensuring that it did not get bogged down in Rwanda and incur unacceptable costs in the pursuit of its limited objectives. ${ }^{54}$

There were a number of incentives for the Security Council formally to provide France with a mandate to intervene. First, the interests of other major powers engaged in the conflict were only humanitarian concerns, sufficient for them to support a UN peacekeeping operation and pay their financial assessment when faced with international demands that something be done to halt the slaughter, but not to contribute forces. The deployment of a temporary French military force would further UN humanitarian objectives in a timely manner and thus advance the minimal interest of the other powers. Second, this would be accomplished at no cost and little risk to the other member states. France, under the mandate provided for its intervention, would assume the burden for the costs of its operation ${ }^{\text {sh }}$ and the presence of its forces would stabilize the situation in the area it brought under its control, facilitating the safe deployment of follow-on UN peacekeeping forces.

\section{Haiti}

The window of opportunity for a successful UN response to the situation in Haiti was narrowed by limited US interests and US concern that the situation might deteriorate. Thus, a consistent feature of the UN response until the spring of 1994 was either not to become involved or, once it had become involved, to limit its role to responses short of the use of force. Haiti is a direct contrast to the other cases, where persistent deterioration of the situation on the ground increasingly narrowed the prospects for a successful response: in Haiti there was relatively little degeneration of the situation, allowing the US to move through the window three years after President Bertrand Aristide was overthrown.

The American decision to resort to force in Haiti was based on a perception that it had immediate interests involved in the crisis. In his address to the nation on 15 September 1994, President Clinton succinctly 
provided the rationale for US military intervention in Haiti, saying: 'the United States must protect our interests - to stop the brutal atrocities that threaten tens of thousands of Haitians, to secure our borders and to preserve stability and promote democracy in our hemisphere and to uphold the reliability of the commitments we make, and the commitments others make to us.' ${ }^{\prime \prime}$

The United States did not so much decide after careful deliberation to resolve the crisis even through the use of force, as it was driven to do so because of its inability to sustain a consistent policy on Haitian refugees. A key aspect of the crisis for the United States was how to handle the problem posed by the large number of refugees fleeing from Haiti to the United States. The Clinton administration was faced with domestic pressure to accept all refugees on humanitarian and political grounds on the one hand, and with concern about the political and domestic consequences of accepting a large number of refugees on the other. Caught on the horns of this dilemma, US policy on Haitian refugees flip-flopped several times, seeking by turns to avoid the problem by turning all refugees back and then permitting refugees to seek asylum in the United States. The turning point came in early May 1994, when under strong political pressure from a range of domestic constituencies, the Clinton administration felt compelled to end its policy of sending all refugees back to Haiti. Not only did this eventually result in a minor flood of refugees, it forced the administration to confront the fact that it would have to resolve the crisis in Haiti if it was ultimately to solve the problem posed by Haitian refugees. The fact that the refugee exodus from Haiti had immediate domestic considerations was sufficient to push the United States over the lower threshold.

In tandem with this change in policy on the refugee problem, the United States embarked on a campaign to force the Haitian military leadership from power. ${ }^{.2}$ This renewed commitment to resolve the crisis invoked the issue of US credibility to fulfil its obligations, and more specifically, the credibility of President Clinton. The US withdrawal from Somalia, its soft approach to dealing with North Korea, its continued waffling on how to handle Haitian refugees, its recall of the USS Harlan County when confronted by an armed Haitian mob, and Clinton's unwillingness or inability to fulfil his campaign promises regarding the former Yugoslavia, raised severe questions about the resolve of the Clinton administration to undertake and carry out its commitments, especially if these involved the use of military force. As a consequence, a failure to achieve the objective of ousting the military leadership in Haiti would undercut what remaining credibility the United States and the President had, while a success would restore some measure of credibility to US policy.

Related to the question of US credibility was concern about the wider 
consequences should the coup leaders be allowed to remain in power. Should the international community fail to reverse the coup and restore democracy in Haiti, anti-democratic forces and potential despots elsewhere in the Latin American and the Caribbean region might be emboldened to seize control in the belief that the international community would not act strenuously against them. This apprehension was shared by many countries in the region, and by among those nearest to Haiti in particular. ${ }^{63}$ The US action thus served to reassure those governments most concerned about its commitment to democracy and to signal to anti-democratic forces that the United States would not tolerate the overthrow of legitimate elected governments in the Caribbean and Latin America.

The United States was able to intervene in Haiti to support these nebulous interests because it could do so without a great risk of substantial loss of life. In spite of a last-minute negotiated deal with the coup leaders, the United States inserted an irresistible military force with a mandate for imposing order in Haiti. The incentives for Washington to obtain a mandate for its actions from the Security Council were much the same as those for France in Rwanda. First, a UN mandate provided international political support and legitimacy for an American action designed to secure its interests. Second, a UN mandate allowed the United States to claim that it was acting to further the organization's objectives and thus avoid assuming sole responsibility for dealing with Haiti. UN Resolution 940 established that the United Nations Mission in Haiti (UNMIH) would replace the USled force and assume responsibility for a revised and expanded mandate to create an environment suitable for free and fair elections. The Clinton administration would thus be able to limit the costs to the United States and to forestall domestic criticism that the United States had been committed to an open-ended operation. The member states of the Security Council, for their part, had a number of incentives to legitimize the US action. The United States, though acting to protect its own interests, would further the established objectives of the UN with respect to Haiti. In particular, forceful US action would remove a regime that had openly defied the UN and blocked the deployment of UNMIH. As well, the United States offered a number of side payments to gain the support of the Security Council. It assumed the total cost of implementing its temporary operation. ${ }^{\star \star}{ }^{4}$ Russia, for its part, supported the US intervention in Haiti in order to gain leverage to act in its own backyard, ${ }^{.5}$ and succeeded in gaining UN endorsement for its troop presence in Georgia as a peacekeeping force. ${ }^{\text {sh }}$

\section{Conclusions}

The growing disconnection from important international affairs and the 
greater complexity of many current disputes located in the developing world suggests that, in future, the major powers will be increasingly reluctant to become involved, with a consequent narrowing of the window of opportunity for successful UN operations. The major powers can and will act rapidly, however, if and when they perceive that they have interests at risk in a dispute or interests that can be furthered by responding to a dispute, even though others are unwilling to respond. The marginalization of most disputes from important global affairs suggests that the major powers are most likely to respond to situations that affect their spheres of interest. In part they will be willing to do so because they individually command the financial, material and manpower resources to secure their particular interests. When their interests are limited, their possession of a large capability, or their perception that they have sufficient capability, may depress the lower threshold of the window for a successful operation. ${ }^{67}$

A common theme in the three cases examined was a perception by a major power that it had interests involved in a dispute, or some aspect of a dispute, sufficient to warrant some form of action, whereas other states and other major powers did not. As a consequence, these states were willing to become engaged when the UN was willing to avoid or limit its involvement in the crisis because of the reluctance of members to participate in the management of disputes they did not perceive as being significant or, in the case of Yugoslavia, because by the time the conflict assumed significance it had degenerated to the point where it defied easy resolution.

In the cases of $\mathrm{R}$ wanda and Haiti the major power was able to gain a UN mandate to take action because the other major powers and members of the Security Council, not having any interests or at least any significant interests at risk in the dispute, were willing to let them have their way rather than attempt to foil them. This suggests that major powers will be able to obtain UN authority when they want to act, should they desire it, because they are operating within their sphere of interest; other states which have the power to block a supporting UN resolution are unlikely to object because they do not perceive that they have any interests at risk or that their interests would not be harmed by the initiating major power's actions. In both cases - the French intervention in Rwanda and the US intervention in Haiti - the acting major power provided side payments to ensure UN support for their military operation. This suggests that if a major power considers the issue to be important, other states may also be willing to let it have its way because they can gain side payments that outweigh any benefit they might realize from blocking its initiative.

Another feature worth noting is that, in the case of the US-led intervention in Haiti, the UN became involved through the provision of a follow-on operation in a dispute in which it had earlier sought to avoid or to 
do only the minimum necessary. The UN had little alternative but to become more seriously engaged if the gains made by the United States in dealing with the Haitian civil dispute were not to be lost. Moreover, while the United States remains the single largest contributor, the UN in effect is carrying part of the burden of solving a problem that the United States, but not all of the other members of the UN, perceived as troubling enough to respond to in a significant way. This suggests that there is a realistic risk of the UN being dragged into and/or providing resources to operations that it otherwise might prefer to avoid or simply to contain when a major power intervenes to protect or further its sphere of interest.

The possibility that the major powers may increasingly authorize the UN to act only when it serves their interest, or act unilaterally with a symbolic mandate from the UN to further their interest, is exemplified by the recent shifts in US policy towards peacekeeping. The United States is the remaining superpower and its support is critical to the future success of the UN. Presidential Directive Decision 25 (PDD-25), promulgated on 3 May 1994, sets forth a cautious and self-interested US policy on multilateral peace operations which concludes that properly conceived and wellexecuted peacekeeping can be a very important and useful tool of American foreign policy'. A primary criterion for UN support for, or participation in, UN peace operations is whether they advance US interests. The document also recommends that the United States reduce its contributions to the UN peacekeeping budget from around 30 per cent to 25 per cent by the end of 1995. The dramatic success of the Republicans in the 1994 mid-term election serves to accentuate neo-isolationist and unilateralist strains in US foreign policy. The apparent US retreat from multilateralism suggests that there will be even less American support for UN operations in the future except when these serve US interests.

A critical question which arises from these observations is how may the UN reduce its dependence on the major powers and thus be freer to respond to disputes? Unless the UN can get around the need to depend on the support of the major powers, it is unlikely to be able to respond to disputes that are: outside of spheres of interest yet which require large-scale operations; on the edge of spheres of interest, but where major power interest is primarily to avoid spillover, and which also require large-scale operations; or any other situation in which major powers are unlikely to have a significant interest at risk, or are likely to be interested only in limiting its impact.

The requirement of major power support for UN involvement, at least in a passive, tolerating sense, cannot be avoided so long as the organization is dependent on major power financial resources and so long as it requires Security Council authorization for creating an enforcement mandate. The 
first, financial factor, together with more active forms of major power involvement, could perhaps be reduced somewhat, a possibility that will be addressed below. Let us, initially, address the role of the Security Council as authorizing body for operations.

It seems unlikely that states in general, much less the Security Council, and the major powers more particularly, would delegate this high political function to the UN bureaucracy, unless they retained some mechanism to oversee its exercise. Efforts to break the Permanent Five's right of veto could also be difficult; they are unlikely to agree readily to this diminution of their power and, given that Charter amendments are themselves subject to the veto, targeting this as a first step to improved UN performance could well postpone serious improvements to the Greek kalends. Efforts to 'democratize' the Security Council are equally suspect; the Security Council represents power and interest, not some ill-defined, latent 'democratic' teleology. Trying to devise essentially artificial ways to 'force' the strong to do something which they do not want to do is more likely to bring their refusal and, in its wake, bring the UN into disrepute, than to succeed. Reforming the Security Council, in fact, might indeed bring it more into line with the current distribution of power (something rather different from 'democratizing' it), but this would not necessarily solve the basic problem. That problem is the dependence of the UN on the powerful, at least passively if not actively.

This leads to three fundamental questions. First, could at least the active dependence of the UN on major powers be reduced, for example through greater involvement by middle and smaller states? Second. could such involvement address the fundamental issues of speed, size and mandate which affect the ability of the UN to move through a window of opportunity and to act successfully? Third, is there any real reason to belicve that middle and small states would be willing to take up the necessary burden? We will briefly address the first two question; the third we leave as a challenge.

An organization dependent on the action, not just tolerance of action, of major powers must necessarily be constrained by the willingness of these to get involved in a conflict management effort. If the interest of these states is limited, and their willingness to commit resources and bear the costs limited. the organizational response must necessarily also be limited. Getting them to 'do more' is one line of response, but it addresses the effect of the constraint. not the constraint itself. If, however, the minimum necessary, especially to deal with disputes that are outside of or only peripheral to major interests, is simply their passive toleration, it might be possible to secure that passive toleration more readily if they are not likely to be called on to bear the burden. In effect, this line of response argues the need to reduce dependence on the major powers, for personnel, for money, for other modes of support 
than simply the willingness to authorize an operation. There will still be a dependence on the major powers' toleration, but this is more a passive than active dependence, befitting the more passive role assigned to the major powers.

Unfortunately, such an approach requires other states to shoulder more of the burden of peacekeeping and to organize to discharge that burden more effectively. The first will not be popular, since principles of the equitable sharing of burdens will be offended. But if dependence on the major powers has a price, so does reducing that dependence. The second requires devising means to address speed, size and mandate issues.

In basic terms, reliance on the major powers could be reduced through a development of a standby force arrangement, placing a number of brigadeequivalents, and their requisite supply, transport, command and control needs, ready for UN duty on short notice. Current efforts to develop a standby force structure are of interest in this regard..$^{.4}$

Whether or not such a 'rapid reaction' force would be designed only to move in quickly and then eventually be replaced by more traditional international forces, or would replace the traditional concept, is a significant but here secondary matter. Of particular importance is the need for certain requirements to be met. First, such a force would have to be ablc, even if backed up by more traditional forces, to meet two or more demands (and preferably more than two) at the same time. Second, such a force would have to be trained (preferably jointly), structured and equipped to handle situations varying in scale, type and intensity of operations. Whether this would include heavy combat (and thus some heavy weapons capability) we leave open, but with the note that heavy combat operations are likely to require major power action. Third, the states contributing to such a force would have to be willing to take losses. If this were not the case, the first blooding of the force could well mean the end of the concept. As well, if the force were committed in a situation that degenerated into heavy fighting, its inability or unwillingness to control the situation would proclaim its irrelevance. Yet, if it got trapped in such a situation, who would rescue it? The major powers? Fear that they might have to contribute to a rescue operation undoubtedly would reduce their willingness to approve such a force in the first place.

A willingness to shoulder a greater financial burden would also be needed, since otherwise the UN would still be restricted by its financial dependence on the major powers. At least for the formation, training and deployment of such a standby force, this suggests a budgeting arrangement other than that used for either the regular UN assessment or the peacekeeping assessment scale. ${ }^{71}$ It might seem reasonable to argue that the peacekeeping scale should come into play when the force is deployed, but 
then major power willingness to finance its operations in the field also becomes necessary. One could go so far as to advocate giving the UN its own income sources, under its control and sufficient to meet this financial need, but states recognize the importance of the power of the purse-strings, and may be unwilling to relax this very far.

Such a standby force would have to meet the three requirements of speed, size and mandate; it would have to be able to move to a trouble spot in sufficient time, with sufficient force and with a mandate to use that force, to prevent a further degeneration. Otherwise, the force would merely repeat some of the recent UN history. This does suggest that contributing states would have to be willing to give up greater control over their forces than has been the case in the past, and then would have to be willing to see that commitment (partly out of their hands) through. This is not quite the same as the UN asking for a blank cheque for the commitment of forces, but it does raise serious political and constitutional issues. It may well be that a co-ordinating group, something along the lines of the Military Staff Committee and composed of contributors, would be required for an oversight and advising function.

A functionalist approach would suggest that middle and small states willing to shoulder a greater burden of UN peacekeeping operations should have their increased participation and contribution recognized in the form of enhanced influence. In the least, such states, as significant providers of peacekeeping forces and capabilities, could better assert their right to a greater say in the deployment, mandate and running of UN operations." Middle and small peacekeepers could increase such derived influence if they co-ordinate amongst themselves. Security Council resolutions require a majority of nine; thus seven votes constitutes a blocking group, and even something less might be significant if the group is working with the Secretary-General. Co-ordination amongst middle and small peacekeeping states willing to contribute more to UN operations opens the possibility of a caucus that may be able to take initiatives, especially when the major powers are unwilling to do so, and also to block, hinder or amend initiatives they do not like. Such a group may not be able to block all major power initiatives, but it may be able to temper the blatant use by a major power of the UN or UN mandates to further sphere of interest goals, if only by providing a sizable force to the operation. ${ }^{72}$ The effectiveness of such a group of middle or small peacekeeping states being able to provide a counter to major power dominance and influence in the UN would be enhanced if it worked closely with the Secretary-General."

Finally, of course, there is the third question. Finding a means to reduce the UN dependence on major powers, so that the organization may better handle disputes that do not touch significantly on their interests, presents a 
number of technical and political problems which would have to be raised and addressed effectively. But a more fundamental issue is whether middle and small states, looking for ways to improve and strengthen the UN especially in such disputes, are willing to ask of themselves what they are asking the major powers to do. If they are not, the UN may very well be reduced, as Boutros Boutros-Ghali suggested, to contracting out many, if not most, peace support operations to regional organizations or to major powers that have a special interest in a dispute.

\section{ACKNOWLEDGEMENTS}

An earlier version of this article was presented at the 'United Nations at Fifty' conference, Saskatoon, Canada, March 1995 and at a special lecture to the Security Studies Research Programme, University of Birmingham, UK, July 1995. We are grateful to the participants of these meetings and to Patrick James, Jerry Sorokin, Frank Harvey, Stuart Croft and the anonymous referees for their comments

\section{NOTES}

1. See Barbara Crossette, 'U.N. Chief Ponders Future of Peacekeepers', The New York Times. 3 March 1995.

2. The terms 'sphere of influence' and 'sphere of interest' are often used interchangeably. By a 'sphere of influence' we inean a region in which a single power, usually external and often adjacent, exerts a predominant influence which restncts the independence or freedom of action of states within it. By 'sphere of interest' we mean a region in which a state, which may be external, has strong or vital interests engaged and in which that state may be the dominant power. A sphere of interest may be co-extensive with a sphere of influence, or may extend beyond a sphere of influence.

3. 'Success' is an important but also difficult term to define. Peacekeeping has been more successful than collective security as a mode of conflict management, for example, but in stgnificant part this is because it has been much less ambitious. Typically, UN success has been assessed in terms of goals ranging from merely mitigating the effects of a conflict or preventing its spread, through reducing the level of violence to at least some degree or even stopping the fighting, to reaching a settlement. It might reasonably be expected that it would be more successful precisely where less ambitious, though even that is merely a hypothesis. not necessarily an empirical truth. In defining 'success' we mighe thus ask: (a) what were the apparent or declared objectives of an operation, and (b) how successful was it in achieving its declared goals. We could then go on to ask: (c) how significant those objectives - thus. the success if any - were.

4. Stanley J. Michalak, for example, has argued that: 'those nations who will bear the major burdens of any enforcement action will not heavily engage themselves in sanctions or military actions where costs and risks may be high and returns in terms of their own national interests would be minimal.' Michalak, 'The United Nations and the League', in Leon Gordenker (ed.). The United Nations in International Politics. Princeton: Princeton University Press, 1971, p. 101. See also Ernst B. Haas, Robert L. Butterworth, and Joseph S. Nye. Conflict Management by International Organizations. Morristown, NJ: General Learning Press. 1972. p.2; Haas, 'Regıme decay: conflict management and international organizations, 1945-1981', International Organization, Vol 37, No.2, 1983, p.191. The ranks of the major powers would include, of course, the permanent, veto-wielding members of the Security Council. More generally, avoiding a purely military definition, we could 
define a major power. whether regionally or globally, as a state of recognized general significant capability, especially to the degree that its support or toleration of an operation or intervention is considered crucial in affecting the likely success or the difficulty of the operation or intervention. Merely being a significant transit point for logistics would not be sufficient, for example. This rough definition is somewhat circular and circumstantial, but then so is reality.

5. James F. Keeley and Terry Terriff, 'Moving Through the Window of Opportunity: The United Nations, Conflict Management and Major Power Interests', in Ron Wheeler and W.C. McConnell (eds), The United Nations at Fifty (forthcoming).

6. For this essay we drew on Michalak, 'The United Nations and the League': N.A. Pelcovits and Kevin L. Kramer, 'Local Conflict and UN Peacekeeping', International Studies Quarterly, Vol.20, No.4, Dec. 1976 pp.533-52: Robert Lyle Butterworth. 'Do Conflict Managers Matter? An Empirical Assessment of Interstate Security Disputes and Resolution Efforts, 1945-1974'. International Studies Quarterly, Vol.22, No.2. Junc 1976. pp. 195-214: Mark W. Zacher, International Conflicts and Collective Security, 1946-77. New York: Praeger, 1979; Jonathan Wilkenfeld and Michael Brecher, 'International Crises, 1945-1975: The UN Dimension'. International Studies Quarterly, Vol.28, No. 1, 1984, pp.45-67; and a series of studies involving Ernst Haas: Haas, Butterworth and Nye, Conflict Management by International Organizations; Haas, 'Regime decay' and 'Collective Conflict Management: Evidence for a New World Order?', in Thomas G. Weiss (ed.), Collective Serurity in a Changing World, Boulder, CO: Lynne Rienner, 1993, pp.63-117.

7. Although our focus is on the UN, the broad window concept could be applied to other actors, including both regional organizations and even individual powers, engaged in conflict management efforts. Indeed, some aspects could also potentially overlap into (or benefit from considerations of) the occurrence and success or failure of interventions more generally.

8. This may show up in terms of crises involving military violence versus those that do not. See Wilkenfeld and Brecher, 'International Crises, 1945-1975', pp.53,55,56-7; Pelcovits and Kramer, 'Local Conflict and UN Peacekeeping', p. 543 ; Haas, Butterwonth and Nye, Conflict Management by International Organizations, pp.15-16,34-35; and Haas, 'Regime decay'. p. 206

9. Haas, Butterworth and Nye Conflict Management by International Organizations, pp. 18-19.

10. This does not mean, of course, that there was no success in these disputes, but rather that the degree and likelihood of success cuuld be less, in part because such situations were not seen as requiring major efforts. Less successful means include the more traditional modes for the peaceful settlement of disputes in which the UN may play a facilitative role but does not go much beyond this. Ibid., pp.34-5,37-8; and Haas, 'Regime decay', pp.71-3.

11. As Haas observed: 'The adage that without substantial effort no impact is scored holds now as it did before, as does the finding that the membership makes little effort to mediate or conciliate in low-intensity disputes.' Hans, 'Regime decay', p.71

12. Similar possibilities are suggested by the character of the parties to a dispute: disputes annong small states showed some success, and those involving middle states still more, but UN success was least as extremes of size (smallest, large and superpower), were approached. Ibid.

13. 'Mission lag' occurs when a UN force, inserted into a situation with a certain size, mandate and other characteristics, finds that situation degenerating beyond its ability to exert control or when delays in inserting the force mean that the situation has already degenerated from the time when the force was initially authorized and defined. 'Mission creep' can occur as a UN operation alters its size, mandate and other characteristics in an attempt to overcome 'mission lag', in the direction of trying to catch up to a degenerating situation.

14. In both cases the combined percentages of 'moderate' and 'great' success are still significant, especially in the latter case, but there is still a significant reduction in the great success category. In the case of major fighting to destroy an enemy, the percentage of cases with merely 'some' success declines radically, while the percentage with no success increases significantly; as outside third parties become involved, the percentages of cases with no success increases very significantly, but the instance of 'great' success disappear. Haas. Butterworth and Nye, Conflict Management by International Organizations. pp.17-19. 
Wilkenfeld and Brecher note that high-level UN activity seems more likely to control escalation. Wilkenfeld and Brecher, 'International Crises, 1945-1975', pp.62-3.

15. Haas, Butterworth and Nye, Conflict Management by International Organizations, p. 20.

16. Ibid; Wilkenfeld and Brecher, 'International Crises, 1945-1975', pp.58-9: and William J. Durch, 'Getting Involved: Political-Military Context', in Durch, The Evolution of UN Peacekeeping, New York: St Martin's Press, 1993, pp.22-3. Haas, Butterworth and Nye found that when a broad consensus - in which Great Powers either supported, went along with, or abstained from resolutions - could be developed among the member states, the prospects of UN success were greater. See Conflict Management by Insernational Organizations, p.32.

17. Pelcovits and Kramer, 'Local Conflict and UN Peacekeeping', pp.547-8, 551

18. Butterworth. 'Do Conflict Managers Matter?'. p.209; and Pelcovits and Kramer, 'Local Conflict and UN Peacekeeping', pp.546-7.

19. The UN was more successful in managing the former than the latter when it did act. See Haas, Butterworth and Nye, Conflict Management by International Organizations, pp.18-19; Wilkenfeld and Brecher, 'International Crises, 1945-1975', p. 58

20. Haas, Butterworth and Nye, Conflic Management by International Organizations, pp.18-19.

21. Ibid., pp.25-6.

22. Ibid., p. 20

23. Ibid.

24. Jbid., pp 25-6; Zacher, International Conflicts and Collective Security, pp.64.68

25. Haas, Butterworth and Nye, Conflict Management by International Organizations, p.20.

26. Zacher, International Conflicts and Collective Security, pp.73,75-9

27. Linda B. Miller, 'International Organizations and Internal Conflicts: Some Emerging Patterns of Responses', in Leon Gordenker (ed.), The United Nations in International Politics, Princeton, NJ: Princeton University Press, 1971, p.139.

28. This, of course, is somewhat conditioned by the ability of such parties to act. If they cannot. the UN could be resorted to. As well, there is the 'CNN factor', especially for humanitarian operations. Impacts may be largely local or regional, but widespread publicity generates a demand to 'do something'.

29. Has, Butterworth and Nye. Conflict Management by International Organizations, pp. 23-4 The UN mostly neglected disputes amongst the smallest nations, particularly when they were not linked to larger global issues such as de-colonization or the Cold War. They suggest, with qualifications, that regional organizations were likely to have a greater chance of managing a conflict between weak states.

30. Zacher. International Contlicts and Collective Security, p.63.

31. Haas, 'Regime decay', pp.207-8.

32. For example, in 1993 there was not one interstate war, while there were 47 intrastate conflicts. See Peter Wallerstein and Karin Axell, 'Conflict Resolution and the End of the Cold War, 1989-93', Journal of Peace Research, Vol.3I, No.3, 1994, pp.333-49.

33. UNDIR Newsletter, No.24, Dec. 1993, pp.37-57

34. In contrast, during the postwar and Cold War period (roughly 1945-87), there were 13 UN operations - seven interstate and six intrastate. Current UN operations relating to interstate conflict are UNIIMOG (Iran-Iraq), UNIKOM (Iraq-Kuwait), MINURSO (Western Sahara), and UNPROFOR (Yugoslavia).

35. The six with connections to the Cold War rivalry are ONUSL (El Salvador), ONUCA (Nicaragua), UNTAC (Cambodia), UNIVEM I and UNIVEM II (Angola), UNOMOZ (Mozambique), and UNGOMAP (Afghanistan). The rest are UNTAG (Namibia), UNOMSA (South Africa), UNOSOM and UNOSOM II (Somalia), UNOMUR (Uganda), UNOMIG (Georgia), UNOMIL (Liberia), UNMIH (Haiti), and UNAMIR (Rwanda).

36. Thomas G. Weiss, 'The United Nations and Civil Wars', Wushington Quarterly, Vol.17. No.4. autumn 1994, p. 140

37. See, for example, Paul F. Diehl. International Peacekeeping, Baltimore and London: Johns Hopkins University Press, 1993, pp.77-9.

38. Along these lines, and for much the same reasons, Michael Mandelbaum suggests a probable disengagement of the US and Europe from much of the world - a reluctance to do more, 
perhaps, than simply the minimum necessary to prevent spillover or to respond to humanitarian crises. Mandelbaum. 'The Reluctance to Intervene', Foreign Policy, No.95. 1994, pp.3-18.

39. For an examination of the narrowing of the 'window of opportunity'. see Keeley and Terriff, 'Moving Through the Window of Opportunity'

40. The United States has provided a field hospital for UNPROFOR and there are a number of US military advisers present in Bosnia.

41. In the wake of the 'Breadline Attack', Secretary of State James Baker said: 'Anyone who is looking for reasons not to act or arguing somehow that action in the face of this kind of nightmare is not warranted at this time - I think that in the view of all of us in the civilized world at least - is on the wrong wavelength.' US Permanent Representative to the UN, Edward Perkins, in condemning the Serbian aggression in Bosnia, stated that 'the aggression of the Serbian regime and the armed forces it has unleashed against Bosnia and Hercegovina represent a clear threat to international peace and security'. Baker. 'Helping the New Independent States; Sanctions of Serbia/Montenegro'. US Department of State Dispatch, I June 1992, p.430): and Edward J. Perkins. 'Aggression by the Serbian Regime'. US Department of State Dispatch, 8 June 1992, p.448

42. Quoted in Don Oberdorfer, 'The Bloody Failure in the Balkans', The Washingtun Post National Weekly Edition, 15-21 Feb. 1993.

43. Unlike the Bush letter, which was kept private, Secretary of State Warren Christopher publicly warned: 'We remain prepared to respond against the Serbians in the event of a conflict in Kosovo caused by Serbian action, and. in addition, we will work to strengthen the international presence in Macedonia. 'Statement of Secretary of State Warren Christopher. 'US Initiatıve on Yugoslavia', CNN, 2:() PM MST. Feb. 1993.

44. See UN Docs S/25954 and S/Res/842. This number was subsequently bolstered to 500 .

45. See U.S. commits ground troops to Macedonia to deter fighting', The Globe and Mail (Toronto), 11 June 1993.

46. See Elaine Sciolino, 'U.S. Says It Will Send 30) Troops to Balkan Republic to Limit Strife'. The New York Tïmes, 11 June 1993.

47. See Douglas Jeh], 'Clinton Outlines U.S. Interest in Bosnia Air Strikes', The New York Times, 10 Feb. 1994. National security advisor Anthony Lake was more succinct, saying that Bosnia 'presents a clear challenge: to NATO's credibility and to [the US] vision of a postcold war Europe.' Quoted in Anthony Lewis, 'Words and Deeds', ibid. 11 April 1994.

48. See Christopher, 'US Initiative on Yugoslavia', for a comparison of the two statements of US interests.

49. Quoted in R.W. Apple, 'Allies Seem Near Accord to Bolster Bosnia Force', The New York Times, 2 June 1995

50. Quoted in Steven Engleberg and Alison Mitchell, 'Seesaw Week for U.S. Tactics in the Balkans'. The New York Tïmes, 5 June 1995

51. Quoted in Michael Dobbs, 'On the Horns of a Foreign Policy Dilemma', The Washingtun Post National Weekly, 24-30) July 1995.

52. As a French official observed, the United States is supposed to be the dominant leader of the Atlantic alliance and yet it refuses to get involved in settling Europe's worst security conflict. What are Europeans to conclude from that.' Quoted in Ann Devroy and Bradley Graham. 'Miscalculations at the White House', International Herald Tribune. 6 June 1995.

53. The Clinton administration was also motivated to take a more forceful role because Congressional activism raised concern that it might lose control of its ability to determine the American foreign policy agenda and because of concern about the impact of a failure to act would harm the President's re-election chances in 1996.

54. Quoted in Marlise Simons, 'A world power flexes its muscle', The Globe and Mail, 5 July 1994.

55. These are Gabon, Djibouti, Senegal, Rwanda (until April 1994), Chad, the Ivory Coast, and the Central African Republic.

56. See Simons, 'A world power flexes its muscle', Peter Maser, 'Rwanda: France once again is being Africa's premiere gendarme', Calgary Herald, 12 July 1994; and 'France and Africa', The Economist, 2.3 July 1994. pp.21-3. 
57. Having recently devalued the Communauté Financière Africaine Franc, which many francophone African states viewed as a betrayal, France was likely particularly keen to seize any opportunity to demonstrate its continued support for its African friends and allies.

58. This possibility is supported by repeated reports that the French troops accepted, and allowed free rein within the French protection zone to, members of the former government, army, and militia, all of whom were implicated in the genocidal attacks against the Tutsi population.

59. SC Res. 929 limited the French mission to a period of two months, unless the SecretaryGeneral determined an earlier date. UN Doc. S/Res/929, 22 June 1994.

60. SC Res. 929 authorized the French intervention on the understanding that the cost of implementing the offer will be borne by the Member States concerned.' UN Doc. S/Res/929, 22 June 1994

61. 'Clinton Tells Nation Haiti's Despots "Must Move Now"', United States Embassy Text, 94-20, 16 Sept. 1994.

62. US strategy was to orchestrate international support for its effort to resolve the crisis, push for the expansion of the UN embargo and indicate publicly that it might be willing to use force. This was backed by obvious military preparations to invade Haiti should the coup leaders not step down

63. As William S. Grey 111, President Clinton's special adviser on Haiti, put it: 'Those whose house is adjoined, next to Haiti, are very concerned and don't want to debate how many buckets of water will be thrown on the fire per minute. Those who are across the strect have a different point of view.' Quoted in Steven Greenhouse, 'A Haiti Invasion Wins Hemisphere Support', The New York Times, 13 June 1994.

64. SC Res. 940 was passed with 'the understanding that the cost of implementing this temporary operation will be borne by the participating Member States.' UN Doc. S/Res/940. 31 July 1994. See also Richard Lyons, 'U.S. gets approval to invade Haiti'. The Globe and Mail, I Aug. 1994.

65. This assessment was offered by Yeltsin aide Andranik Migranyan. See "A "Yeltsin Doctrine"', Newsweek, 10 Oct. 1994.

66. See Geoffrey York, 'Russia watches the near-abroad', The Globe und Mail, 19 Dec. 1994; UN Doc. S/Res/937, 21 July 1994. Russia has been seeking to gain international legitimacy for its peacekeeping efforts in its near abroad. These efforts also appear to reflect sphere of interest considerations, for Russian concepts of peacekeeping in its 'near abroad' are underpinned by Moscow's perception that it needs to manage this region to protect its own security. See, for example, S. Neil MacFarlane and Albrechi Schnabel. 'Russia's approach to peacekeeping', International Journal, Vol.L, No.2. Spring 1995, esp. pp.307-20; and Maxim Shashenkov. 'Russian Peacekeeping in the "Near Abroad"', Survival, Vol. 36, No.3, Autumn 1994, esp. pp.49-51.

67. Major powers which are willing to act, however, do not escape the window of opportunity problem: they run up against the same imperative of needing to engage with an appropriate response (in terms of time, scale and mandate) as does the UN. A major power may be willing to act, but if its interests are limited its response is also likely to be limited. As a consequence, a major power may intervene with forces and a mandate which are sufficient to achieve its specific objectives, but which are insufficient to have any significant impact on the dispute or to keep on top of escalation.

68. 'United States: Administration Policy on Reforming Multilateral Peace Operations [May 1994]', 33 International Legal Materials 705 (1994), pp.802-3.

69. See, for example, the Canadian proposal for the development of a UN rapid reaction capability. Government of Canada. Tewwards a Rapid Reaction Capability of the United Nations, Ottawa: Government of Canada, Sept. 1995.

70. For the former, a handful of states pay 70 per cent of the regular UN budget; for the latter, the Permanent Five pay approximately 56 per cent and a second group of 22 states pays about 41 per cent. US General Accounting Office, United Nations: U.S. Participation in Peacekeeping Operations, GAO/NSIAD-92-247, Sept. 1992.

71. An assumption of a greater share of the peacekeeping burden would give increased weight to the Canadian argument that it and other peacekeeping contributors be given some from of semi-permanent membership on the Security Council in recognition of their perennial 
commitment to the UN

72. For example, the Organization for Security and Co-operation in Europe managed to block a Russian initiative for an all-Russian force for Azerbaijan in the autumn of 1994 by insisting that half of the forces must consist of troops from other member states

73. This possibility is suggested by Haas, Butterworth and Nye, who noted that, as the salience of the issue increased, the leadership role of superpowers and other large and middle states also increased, as did the leadership of the Secretary-General, but that successful leadership was most probable when the Secretary-General and middle powers worked together. Haas, Butterworth and Nye. Conflict Management by International Organizations. pp.27-30. 